\title{
ROLA ŚRODOWISKA GEOGRAFICZNEGO W DZIAŁANIACH WOJENNYCH PROWADZONYCH NA OBSZARZE BUŁGARII W DRUGIEJ POŁOWIE XIX W.
}

\section{Wpływ środowiska naturalnego na działania wojskowe}

$\mathrm{P}$ roblematyka wpływu środowiska geograficznego na przebieg planowania i prowadzenia wojny jest jednym z głównych obiektów zainteresowania badań wojskowo-geograficznych ${ }^{1}$, określanych terminem "geografia wojskowa (wojenna)”2. Przez środowisko geograficzne utarło się określać „otaczającą

${ }^{1}$ Wśród pozostałych uwarunkowań mających wpływ na prowadzenie działań wojskowych można wymienić czynniki: przestrzenne, gospodarcze, kulturowe, demograficzne, polityczne i wojskowe, J. Tyszkiewicz, Geografia historyczna. Zarys problematyki, Warszawa 2014, s. 139.

${ }^{2}$ Wielu geografów nie traktuje geografii wojskowej jako odrębnego działu geografii, lecz jako "geograficzną wiedzę stosowaną dla celów informacji wojskowej”, Z. PARUCKI, Zarys geografii wojennej, Warszawa 1967, s. 19. Inaczej postrzegali to inni autorzy. Kpt. Franciszek AnToniewsKi-RACZYŃSKI, autor haseł z zakresu geografii wojskowej w trzecim tomie Encyklopedii Wojskowej, zdefiniował geografię wojskową jako: „specjalny dział geografii ogólnej, poświęcony badaniom zjawisk fizycznych, biologicznych i społecznych pewnego środowiska geograficznego (zwykle całego państwa, lub poszczególnych jego obszarów) z punktu widzenia oddziaływania tych czynników na przygotowanie i prowadzenie wojny", Geografia wojskowa, [w:] Encyklopedia Wojskowa, t. 3, red. O. LAskowski, Warszawa 1933, s. 41. Autorzy Małej encyklopedii wojskowej oraz Leksykonu wiedzy wojskowej sytuują natomiast geografię wojenną jako część składową nauki wojennej, Geografia wojenna, [w:] Mała encyklopedia wojskowa, t. I, A-J, red. M. Odlewany, Warszawa 1967, s. 448; Geografia wojenna, [w:] Leksykon wiedzy wojskowej, red. M. LAPRUs, Warszawa 1979, s. 125. Rozbieżności w tym zakresie wynikają, jak należy sądzić, ze zmiany postrzegania nauk wojskowych na przestrzeni ostatniego czasu. W uzupełnieniu tego wątku należy przypomnieć, że w 2011 r. Centralna Komisja do Spraw Stopni i Tytułów Naukowych podjęła decyzję o likwidacji nauk wojskowych, wprowadzając $\mathrm{w}$ to miejsce $\mathrm{w}$ dziedzinie nauk humanistycznych nauki o obronności i nauki 
człowieka przyrodę pojmowaną jako zespół zjawisk i procesów wzajemnie uwarunkowanych i powiązanych"3. Do najczęściej wymienianych części składowych środowiska geograficznego należą: ukształtowanie terenu, sieć hydrograficzna, klimat, budowa geologiczna, gleby oraz świat roślinny i zwierzęcy ${ }^{4}$.

Wśród wspomnianych elementów na czoło wysuwają się kwestie związane z ukształtowaniem terenu. Rzeźba terenu jest bowiem tym czynnikiem, który w dużym stopniu określa główne kierunki działania, może determinować tempo przemarszu wojsk, utrudniać lub nawet uniemożliwiać prowadzenie działań bojowych ${ }^{5}$. Ważną rolę spełnia także sieć hydrograficzna. Morza, rzeki, jeziora i bagna stanowią poważną przeszkodę dla nacierających wojsk. W zależności od kierunku posuwania się oddziałów mogą także ubezpieczać skrzydła i rozdzielać kolumny. Przy ich ocenie decyduje położenie, kierunek biegu i właściwości fizyczne takie jak: rozmiary, głębokość, charakter dna, brzegu oraz prędkość nurtu. Jeziora i bagna tworzą cieśniny, a broniącemu pozwalają małymi siłami powstrzymać przeciwnika ${ }^{6}$. Morza i rzeki mogą stanowić również dogodne do przewozu żołnierzy i zaopatrzenia drogi wodne. Duży wpływ na działania bojowe, zaopatrzenie i stan zdrowotny żołnierzy mają czynniki klimatyczne. W znacznym stopniu warunkują one wyposażenie, wyżywienie oraz zakwaterowanie wojska $\mathrm{w}$ warunkach polowych. Urasta to do wyjątkowo istotnego problemu w strefie mroźnych i śnieżnych zim, gdzie aż do XX w. o tej porze roku działania wojenne na większą skalę zazwyczaj zamierały ${ }^{7}$. Ilość opadów i temperatura decyduje o wysokości wodostanów rzek i jezior, co wpływa na dostępność pewnych obszarów. Budowa geologiczna warunkuje natomiast takie kwestie jak: budowa dróg, schronów i fortyfikacji stałych, doraźne zaopatrzenie $\mathrm{w}$ wodę czy też możliwość korzystania $\mathrm{z}$ lokalnych materiałów budowlanych ${ }^{8}$. Gleby pod względem wojskowym oddziaływają przede wszystkim na dostępność dróg polowych, poruszanie się poza drogami utwardzonymi i budowę umocnień polowych' ${ }^{9}$ Charakter gleb, o czym nie można zapominać, wpływa także na rozwój rolnictwa, a tym samym warunkuje możliwość wykorzystania miejscowych zasobów do wyżywienia wojsk. Różnorodność

o bezpieczeństwie. Szerzej na ten temat: J. Maroń, O osobliwościach polskiej historii wojskowości, Wrocław 2013, s. 62-96. Na temat zakresu badań geografii wojskowej vide: J. Tyszkiewicz, op. cit., s. $142-147$.

${ }^{3}$ Z. PARUCKI, op. cit., s. 17.

${ }^{4}$ Ibidem. Benon Miśkiewicz, pisząc o wpływie środowiska geograficznego na prowadzenie działań wojennych, zwraca natomiast uwagę na takie czynniki jak: warunki topograficzne terenu, warunki atmosferyczne oraz porę roku i doby, w jakich odbywają się walki, IDEM, Wprowadzenie do badań historycznowojskowych, Poznań 2001, s. 130.

${ }^{5}$ Z. PARUCKI, op. cit., s. 77.

${ }^{6}$ H. BAgríski, Studia terenu i metoda opisu terenu, Warszawa 1924, s. 13-14.

7 Z. PARUCKI, op. cit., s. 97; H. BAgIŃsKI, op. cit., s. 15.

${ }^{8}$ Z. PARUCKI, op. cit., s. 74.

${ }^{9}$ H. BagińsKi, op. cit., s. 11. 
opisanych czynników w dużym stopniu oddziałuje na charakter i rozmieszczenie roślinności. Kluczowa rola w północnej strefie geograficznej z punktu wojskowego przypada lasom, które mogą być wykorzystywane do skrytej koncentracji sił i zapewniają ochronę słabszym. Wojska nacierające z reguły obchodzą je dążąc do bezpośredniej konfrontacji $\mathrm{w}$ otwartym polu ${ }^{10}$. Przedstawione powyżej cechy mogą za tym wpływać w bardzo różnorodny sposób na działania zbrojne. W przypadku określonego środowiska geograficznego (obszaru) kluczowe znaczenie będzie miała nie tylko ich znajomość, ale przede wszystkim możliwości przystosowania do zaistniałych warunków ${ }^{11}$.

Celem artykułu jest przedstawienie na wybranych przykładach, jak środowisko geograficzne wpływało na przebieg działań wojennych prowadzonych w drugiej połowie XIX w. na terenie Bułgarii. Aby go zrealizować, niezbędne było omówienie głównych elementów środowiska geograficznego Bułgarii pod kątem wojskowym, scharakteryzowanie trwających w tym czasie wojen (wojna rosyjsko-turecka $1877-1878$ i serbsko-bułgarska 1885 r.) oraz wskazanie przykładów związanych z wpływem czynników geograficznych na przebieg walk.

\section{Środowisko geograficzne Bułgarii}

\section{Budowa geologiczna, gleby i ukształtowanie terenu}

Pod względem budowy geologicznej i ukształtowania terenu obszar Bułgarii charakteryzuje się dużą różnorodnością wynikającą z przebiegającego równoleżnikowo ukształtowania powierzchni. W północnej części ziem bułgarskich znajduje się Równina Naddunajska, która nazywana jest także Niziną Naddunajską. Rozciąga się ona od doliny rzeki Timok na zachodzie do wybrzeży Morza Czarnego na wschodzie. Zbudowana jest $\mathrm{z}$ poziomo zalegających trzeciorzędowych skał osadowych, przykrytych w plejstocenie lessem. Jest to obszar bezleśny i rolniczy z przewagą roślinności stepowej, zastąpionej przez rośliny uprawne. W zachodniej części, graniczącej z Serbią, rzeźba terenu jest na ogół płaska, a równina jest poprzecinana licznymi, krótkimi, krętymi i płytkimi rzekami (zwłaszcza latem), będącymi dopływami Dunaju. Obszar centralny położony między rzekami Iskyrem a Jantrą jest bardziej urozmaicony, średnia jego wysokość jest wyższa niż części zachodniej. Typowym przykładem ukształtowania powierzchni tego odcinka jest Wyżyna Pleweńska. Najwyżej położoną część Równiny Naddunajskiej jest jej obszar wschodni rozciągający się od Jantry po wybrzeże Morza Czarnego. Najwyżej położonym regionem wyżynnym jest tu Wyżyna Szumeńska ${ }^{12}$.

\footnotetext{
10 Z. PARUCKI, op. cit., s. 110-111.

11 J. Tyszkiewicz, op. cit., s. 143.

12 H. Maruszczak, Bułgaria, Warszawa 1971, s. 121-122.
} 
Na południe od Równiny Naddunajskiej rozciąga się Przedbałkan, czyli Przedgórze Staropłanińskie. Jest to obszar pofałdowany, który można porównać do pagórkowatych wyżyn lub niskich gór sięgających w zachodniej części wysokości 900-1000 $\mathrm{m}^{13}$. Dalej na południe od Przedbałkanu rozciąga się wąskie pasmo górskie Bałkan nazywane przez Bułgarów Starą Płaniną. Ciągnie się ono na przestrzeni prawie $600 \mathrm{~km}^{14}$. W większej części ma przebieg równoleżnikowy, tylko w zachodniej części skręca na północ. Składa się ze zróżnicowanych pod względem wysokości, budowy i szaty roślinnej masywów i grup górskich ${ }^{15}$. Dzieli się na trzy części: zachodnią, środkową i wschodnią. Centralna część Płaniny jest najwyżej wyniesioną częścią całego masywu górskiego, ma długość około $250 \mathrm{~km}$ i jest dość urozmaicona. W zachodniej części, zbudowanej ze skał osadowych, góry są nieco niższe (najwyższy szczyt Kom liczy 2016 m n.p.m.), przez co bardziej dostępne. Na ich zaokrąglonych zboczach znajdują się łąki, a poniżej pas lasów iglastych, dalej pas lasów mieszanych i lasów dębowych. Na niższych częściach zboczy górskich rozpościerają się pola uprawne ${ }^{16}$. Najniższa, wschodnia część ma charakter gór niskich. Tworzą ją przeważnie utwory kredowe, które ciągną się aż do Morza Czarnego ${ }^{17}$.

Pomiędzy łańcuchami górskim Bałakanu (Starej Płaniny) na północy i Srednej gory (Antybałkanu) na południu znajduje się pas kotlin zabałkańskich (subbałkańskich). Są to płaskie równiny zapadliskowe, gdzie w dużym stopniu koncentruje się produkcja rolna Bułgarii. Na zachodzie rozpościera się dość duża, zamknięta ze wszystkich stron górami Kotlina Sofijska. Dalej znajduje się kilka mniejszych kotlin - Złatnicka, Karłowska i Kaznłycka tworzące tzw. Dolinę Róż oraz Nizina Burgaska ${ }^{18}$. Pas kotlin zabałkańskich na południu graniczy z niewysokim pasmem górskim Srednej góry. Składa się ono z kilku mniejszych grup górskich (Witosza, Lulin, Wiskajar, Zawalska Płanina) na zachodzie oraz oddalonych od trzonu gór Strandża na wschodzie. Dalej w kierunku południowym rozpościera się system kotlin południowych i należąca do niej Nizina Górnotracka. Jest to rozległa równina o przeciętnej wysokości 150-200 m n.p.m. ${ }^{19}$ W południowo-zachodniej części kraju znajduje się utworzona z łupków krystalicznych Osogowsko-Bełasicka grupa gór, będącą częścią składową masywu

\footnotetext{
${ }^{13}$ Ibidem, s. 122.

${ }^{14}$ IDEm, Bułgaria, [w:] Geografia powszechna, t. III, Europa (bez ZSRR), red. A. WrzoseK, Warszawa 1965, s. 106.

${ }^{15}$ L.W. Lyde, A.F. Mockler-Ferryman, A Military Geography of the Balkan Peninsula, London 1905, s. 53.

${ }^{16}$ H. Maruszczak, op. cit., s. 294.

17 T. Dyвсzyńsкi, Półwysep bałkański, [w:] Wielka geografia powszechna, t. VIII, Warszawa [1939], s. 68.

${ }^{18}$ H. Maruszczak, op. cit., s. 124-125.

19 A. Jelonek, Bułgaria, [w:] Słownik geografii Europy, red. A. Wrzosek, Warszawa 1976, s. 140.
} 
serbsko-macedońskiego oraz Rodopy Zachodnie i Rodopy Wschodnie. Zbudowane ze starych skał krystalicznych Rodopy są rozczłonkowane głębokimi dolinami rzek, $\mathrm{w}$ wyższych partiach mają rzeźbę polodowcową $\mathrm{z}$ wieloma małymi jeziorami ${ }^{20}$. Na wschodzie kraju znajduje się brzeg czarnomorski, w którym dominują formy klifowe, a formy płaskie stanowią jedynie 27\% ogólnej długości wybrzeża ${ }^{21}$. Bułgaria tym samym ma urozmaiconą rzeźbę o przewadze form górzystych zajmujących około $2 / 3$ powierzchni, w tym $26 \%$ zajmują obszary górzyste i góry powyżej $600 \mathrm{~m}$ n.p.m. ${ }^{22}$

Ta pobieżna i siłą rzeczy skrócona charakterystyka budowy geologicznej, gleb i ukształtowania terenu Bułgarii prowadzi do ogólnego wniosku, że jest to obszar trudny do prowadzenia działań ofensywnych na kierunku północ-południe, a to za sprawą masywu Starej Płaniny. Stanowi on poważną przeszkodę w komunikacji, która możliwa jest tylko przez przełęcze leżące na znacznej wysokości, co ułatwia ich obronę przy wykorzystaniu nawet niewielkich sił. Korzystniejszym układem do prowadzenia działań jest kierunek zachodni. Tu jednak musimy brać pod uwagę fakt, że rozciągające się równoleżnikowo pasma górskie kanalizują ruch wojsk i mogą doprowadzić do rozproszenia wysiłku i sprowadzić działania do walk niepozostających ze sobą w styczności oddzielnych kolumn. W sumie ukształtowanie powierzchni Bułgarii sprzyja prowadzeniu działań obronnych i stwarza dla przeciwnika wiele wyzwań w czasie planowania i w trakcie prowadzenia działań ofensywnych.

\section{Klimat}

Czynnikiem decydującym o klimacie Bułgarii jest równoleżnikowy układ gór. Utrudnia on z jednej strony napływ chłodnego powietrza z północy kontynentu, z drugiej zaś ogranicza inwazję ciepłego powietrza z nad Morza Śródziemnego. Powoduje to wyraźne zróżnicowanie klimatu między regionami położonymi w północnej i w południowej części kraju. Na południu mamy klimat śródziemnomorski, natomiast Bułgaria środkowa i północna ma klimat kontynentalny. Średnia roczna temperatura wynosi $+10^{\circ} \mathrm{C}$, najzimniejszym miesiącem jest styczeń, a najcieplejszym lipiec ${ }^{23}$. Maksimum opadów przypada na koniec wiosny oraz jesień lub początek zimy. Średnia roczna suma opadów na nizinach wynosi 450-700 mm, a w górach 600-1200 $\mathrm{mm}^{24}$.

\footnotetext{
${ }^{20}$ Ibidem.

${ }^{21}$ H. Maruszczak, op. cit., s. 127.

22 A. Jelonek, op. cit., s. 138.

${ }_{23}$ Bołgarija, [w:] Woennaja enciklopedija, t. IV, red. K.I. Weliczko [et al.], Peterburg 1911, s. 624.

${ }^{24}$ A. Jelonek, op. cit., s. 141.
} 
Nawet w najbardziej korzystnej porze roku klimat bywa zdradliwy. Bagnisty teren w pobliżu Dunaju jest niezdrowy w miesiącach letnich, a duże różnice temperatur między dniem a nocą występujące na obszarze Starej Płaniny mogą powodować wzrost zachorowalności ludzi i zwierząt. Jesienią (wrzesień) zaczynają się obfite opady deszczu, które stopniowo przechodzą w opady śniegu. Wszechobecna wilgoć sprzyja zwiększeniu zachorowalności na skutek wyziębienia organizmu. Wraz z nastaniem mrozów klimat staje się zdrowszy, jednak warunki egzystencji (marsze, postoje), zwłaszcza w górach, stają się bardzo ciężkie. W tych okolicznościach źle wyekwipowani żołnierze są szczególnie podatni na różnego rodzaju choroby, w tym: udary słoneczne, biegunkę, gorączkę, anginę i inne ${ }^{25}$. Na niżej położonych, zabagnionych terenach poważnym problemem jest malaria.

Przeszkodą dla ruchu wojsk są występujące w okresie jesienno-zimowym gęste mgły, powodujące znaczne ograniczenie widoczności. W warunkach lokalnych potrafią one utrzymywać się przez długi okres. Umożliwiają wprawdzie stronie atakującej skryte podejście, ale dają także możliwość obrońcom zaskoczenia czołowych oddziałów przeciwnika. Towarzyszące temu okresowi częste opady deszczu, a później deszczu ze śniegiem i śniegu zmieniają nieutwardzone drogi w błoto. Lepiąca się do nóg maź stanowi wówczas poważne wyzwanie dla ludzi i pojazdów, spowalniając poruszanie się ${ }^{26}$.

\section{Sieć hydrograficzna}

W odniesieniu do warunków hydrograficznych kluczowe znaczenie ma stan i bieg rzek. Większość z nich toczy wody w kierunku południkowym (z wyjątkiem Dunaju) i są to rzeki typu podgórskiego i górskiego, o zmiennym stanie wód, z maksimum wody na wiosnę. Rzeki te wpadają do Dunaju lub Morza Egejskiego, przez co sieć rzeczna ma charakter układu odśrodkowego ${ }^{27}$. Do północnej zlewni (dopływy Dunaju) należą: Timok, Arczar, Łom, Ogosta i Iskyr, a do południowej (Morze Egejskie) - Niszawa, Jerma, Struma i Mesta. Chociaż nie są to głębokie rzeki, to mogą one utrudniać prowadzenie działań wojskowych z zachodu na wschód i odwrotnie. Na wielu odcinkach płyną one przez góry, tworząc wąskie wąwozy. Kilka mniejszych rzek płynących przez ubogą w opady wschodnią Bułgarię wpada do Morza Czarnego.

Główną arterią wodną jest Dunaj, będący rzeką graniczną. Wzdłuż jego koryta przebiega $470 \mathrm{~km}$ odcinek granicy między Bułgarią a Rumunią. W drugiej połowie XIX w. była to rzeka o znaczeniu międzynarodowym ${ }^{28}$, w pełni spławna

${ }^{25}$ L.W. Lyde, A.F. Mockler-Ferryman, op. cit., s. 68.

${ }^{26}$ Szerzej na temat błota, jego rodzajów i znaczenia w konfliktach zbrojnych, C.E. Wood, Wielkie porażki militarne. Jak pogoda wpłynęła na losy wojen, tłum. M. Kowasz, Warszawa 2007, passim.

${ }^{27}$ H. Maruszczak, Bułgaria..., s. 150.

${ }^{28}$ Dunaj uznany został za rzekę międzynarodową na mocy decyzji paryskiej konferencji pokojowej w 1856 r. Umiędzynarodowienie rzeki dotyczyło tylko jej ujścia. W środkowym jej biegu żegluga 
i żeglowna umożliwiająca wysyłkę towarów i ruch taboru rzecznego na całej długości granicznego odcinka. Okres żeglugowy wynosił średnio 8-9 miesięcy $\mathrm{w}$ roku. Jest to największa przeszkoda wodna dla nacierających wojsk z północy.

\section{Rozmieszczenie roślinności i zwierząt}

Mimo działalności człowieka świat roślinny Bułgarii w dużej części zachował swój pierwotny stan, szczególnie na terenach górskich i słabo zaludnionych ${ }^{29}$. Na obszarach Niziny Naddunajskiej występuje roślinność stepowa i stepowo-leśna, a na terenach wyżej położonych lasy dębowe i zarośla liściaste. W wyższych górach znajduje się roślinność typu środkowoeuropejskiego, ułożone piętrowo lasy bukowe, bukowo-jodłowe i jodłowe oraz świerkowe. Na południe od Starej Płaniny tereny nizinne pokrywa roślinność śródziemnomorska (dęby krzewiaste z domieszką roślin laurolistnych, cyprysowatych i mirtowych) ${ }^{30}$.

Ukształtowanie terenu, gleby, klimat oraz warunki hydrograficzne powodowały, że ziemie uprawne na terenie Bułgarii stanowiły na przełomie XIX i XX w. około $1 / 3$ powierzchni kraju, podobnie przedstawiał się procentowy udział pastwisk i łąk górskich. Czwartą część tworzyły nieużytki, a tylko niewielką część stanowiły lasy około $12 \%{ }^{31}$. Główne skupiska leśne rozmieszczone były na obszarach górskich, gdzie stanowiły około $29 \%$ powierzchni, co dodatkowo utrudniało tam przemieszczanie wojsk i prowadzenie walk.

Świat zwierzęcy, podobnie jak świat roślinny, wykazuje cechy przejściowe od fauny charakterystycznej dla prowincji europejsko-syberyjskiej (niedźwiedź, wilk, sarna, dzik, lis, w górach kozica) do śródziemnomorskiej (bażant, pelikan, żaba grecka i inne) $)^{32}$.

\section{Wojny toczone na terenie Bułgarii w drugiej połowie XIX w.}

Ziemie bułgarskie w drugiej połowie XIX w. były, nie licząc zrywów powstańczych, terenem dwóch poważnych wojen: wojny rosyjsko-tureckiej 1877-1878 i wojny serbsko-bułgarskiej 1885 r. Biorąc pod uwagę obszar objęty walkami, siły biorące w nich udział i czas trwania, były to dwa różne konflikty zbrojne.

Wojna rosyjsko-turecka $1877-1878$ była prowadzona z dużym rozmachem i natężeniem na dwóch teatrach działań wojennych (TDW): bałkańskim i kaukaskim, przy czym ten pierwszy był główny. O jego znaczeniu zdecydowały: najkrótsza odległość do stolicy Imperium Osmańskiego - Konstantynopola i cieśnin

była zdominowana przez Austrię, a później Austro-Węgry, A. KAstory, Żegluga dunajska w polityce międzynarodowej w XX wieku, Kraków 2011, s. 12, 41.

29 T. DyвCZYŃsKi, op. cit., s. 73.

${ }^{30}$ H. Maruszczak, Bułgaria, [w:] Geografia powszechna..., s. 109.

31 M. SiwaK, Geografia Europy, Lwów 1931, s. 57.

${ }^{32}$ H. Maruszczak, Butgaria, [w:] Geografia powszechna..., s. 110. 
oddzielających kontynent europejski od azjatyckiego, życzliwy stosunek miejscowej ludności do Rosjan, traktującej ich jak wyzwolicieli oraz lepsze możliwości komunikacyjne niż na kaukaskim teatrze ${ }^{33}$. Bałkański TDW obejmował cały obszar ziem bułgarskich. Jego umowną granicę stanowiło: na wschodzie - ujście Dunaju do Morza Czarnego, na zachodzie - miasto i twierdza Widyń, na północy - Dunaj, a na południu - Morze Egejskie lub cieśniny tureckie. Ogółem teren ten obejmował około 160 tys. -200 tys. $\mathrm{km}^{2}$. Jego długość (ze wschodu na zachód) wynosiła $400 \mathrm{~km}$, natomiast szerokość (z północy na południe) $400-500 \mathrm{~km}^{34}$. Na tym obszarze starły się ze sobą z jednej strony armia rosyjska wspierana przez wojska rumuńskie i bułgarskie oddziały ochotnicze tzw. opołczenie ${ }^{35}$, z drugiej zaś oddziały armii osmańskiej oraz jednostki korpusu egipskiego.

Zgodnie z rosyjskim planem wojny, w początkowym okresie wojny na Półwysep Bałkański skierowano 254 tys. żołnierzy. Siły te były zgrupowane w siedmiu korpusach, wchodzących w skład dwóch armii. Wojska rosyjskie podjęły działania na trzech kierunkach operacyjnych: nadmorskim, centralnym i zachodnim, przy czym ze względów politycznych i wojskowych najważniejszym był kierunek centralny, gdzie operowały główne siły w liczbie 135 tys. żołnierzy ${ }^{36}$. Głównodowodzącym wojsk rosyjskich był brat cara Aleksandra II, wielki książę Mikołaj. Po drugiej linii frontu w początkowym okresie wojny znajdowało się 186 tys. żołnierzy tureckich, nie licząc żołnierzy znajdujących się w zachodniej części Półwyspu Bałkańskiego, w Tesalii i Epirze oraz w pobliżu Konstantynopola ${ }^{37}$. Głównodowodzącym armii osmańskiej był Abdülkerim Nadir pasza, a od 21 lipca 1877 r. Mehmed Ali pasza (Ludwig Karl Detroit). Przedłużająca się wojna spowodowała, że pierwotnie zmobilizowane siły stały się niewystarczające. Efektem tego było znaczne zwiększenie liczby żołnierzy biorących udział w walkach. Pod koniec 1877 r. w Rosji pod bronią było 942,4 tys. żołnierzy, z czego w szeregach armii naddunajskiej znajdowało się 554 tys. żołnierzy ${ }^{38}$. Rosjan dodatkowo wspierał kontyngent wojsk rumuńskich liczący ponad 30 tys. żołnierzy ${ }^{39}$. Siły armii osmańskiej łącznie ze wspomagającym je korpusem egipskim wynosiły w tym czasie około 650 tys. żołnierzy ${ }^{40}$.

${ }^{33}$ Wojna rosyjsko-turecka 1877-1878, red. I. Rastunowa, tłum. B. Szmielew, Warszawa 1982, s. 57; B. BrodeCKI, Szypka i Plewna 1877, Warszawa 1986, s. 30.

${ }^{34}$ B. BRODECKI, op. cit., s. 27.

${ }^{35} 1 \mathrm{~V} 1877$ r. w szeregach bułgarskiego opołczenia znajdowało się 6238 żołnierzy, Wedomost czislitel'nogo sostojanija bolgarskogo opolczenija (wyboroczno), dok. nr 8, [w:] L.G. BESKROWNYJ, Hrestomatija po russkoj woennoj istorii, Moskwa 1947, s. 472.

36 Wojna rosyjsko-turecka..., s. 61.

${ }^{37}$ M. Uyar, E.J. Erickson, A military history of the Ottomans. From Osman to Atatürk, Santa Barbara-Denver-Oxford 2009, s. 185.

${ }^{38}$ Wojna rosyjsko-turecka..., s. 265.

${ }^{39}$ Ibidem, s. 138.

${ }^{40}$ B. BRODECKI, op. cit., s. 24-25. 
Wojna rosyjsko-turecka 1877-1878 trwała ponad dziesięć miesięcy, tj. od 24 kwietnia 1877 r., kiedy car Aleksander II ogłosił w Kiszyniowie akt wypowiedzenia wojny, do 3 marca 1878 r., kiedy to w San Stefano podpisano traktat pokojowy. Aktywna faza walk na lądzie trwała jednak nieco krócej i rozpoczęła się 22 czerwca 1877 r. i zakończyła 31 stycznia 1878 r. w momencie podpisania zawieszenia broni. W tym czasie tylko straty Rosjan wyniosły około 170 tys. zabitych ${ }^{41}$.

Wojna serbsko-bułgarska 1885 r. miała natomiast charakter krótkotrwałego, ograniczonego konfliktu zbrojnego o zasięgu lokalnym ${ }^{42}$. Działaniami zbrojnymi objęte było zachodnie pogranicze Bułgarii i wschodnie pogranicze Serbii. Jego umowną granicę stanowiła: na wschodzie - linia: Łom, środkowy bieg rzeki Iskyr i górny bieg rzeki Struma, na zachodzie - rzeki Timok, Niszawa i Morawa Południowa, na północy - Dunaj a na południu - granica między Serbią, Bułgarią i Imperium Osmańskim, która biegła wzdłuż Osogowsko-Bełasickiej grupy gór oraz północnych stoków masywu górskiego Riła. Ogółem teren ten obejmował około 32-35 tys. $\mathrm{km}^{2}$. Jego długość (ze wschodu na zachód) wynosiła $180-220 \mathrm{~km}$, natomiast szerokość (z północy na południe) $150-180 \mathrm{~km}^{43}$. Ze względu na ukształtowanie terenu działania zbrojne prowadzone były na dwóch odrębnych kierunkach operacyjnych: północnym (widyńskim) i południowym (sofijskim), przy czym kierunek południowy miał znaczenie priorytetowe.

W momencie wybuchu wojny w szeregach armii serbskiej było 60862 żołnierzy ${ }^{44}$. W tym czasie po drugiej stronie granicy znajdowało się 32237 żołnierzy bułgarskich ${ }^{45}$. Liczba ich jednak szybko wzrosła, za sprawą oddziałów, które przybyły z głębi kraju ${ }^{46}$. W szczytowym momencie wojny po obu stronach łącznie znajdowało się od 108 do 133 batalionów piechoty, 33-39 baterii artylerii i do 31 szwadronów kawalerii. W sumie było to około 120 tys. żołnierzy ${ }^{47}$. Na czele wojujących armii stali ówcześni władcy Serbii - król Milan i Bułgarii - książę Aleksander von Battenberg. Wojna serbsko-bułgarska należy do grupy najkrótszych wojen w historii Europy. Trwała praktycznie od 14 do 28 listopada 1885 r., kiedy to zostało zawarte zawieszenie broni. Oficjalnie konflikt zbrojny

${ }^{41}$ M. Marinow, H. Uzunow, A. Karaiwanow, T. Dakow, Rusko-turskata oswoboditelna wojna 1877-1878, Sofija 1977, s. 209.

${ }^{42} \mathrm{Na}$ temat przebiegu działań wojennych w 1885 r. vide: D. FAszczA, Wojna serbsko-bułgarska 1885 r. Studium polityczno-wojskowe, Oświęcim 2018 (tam obszerna bibliografia tematu).

${ }^{43}$ Istorija na Srbsko-błgarskata wojna 1885 god, Sofija 1925, s. 149.

44 W. DźondźEwić, Istorija Srpsko-bugarkog rata 1885, Knj. prwa, Od Pirota do Sliwnice, Beo$\operatorname{grad} 1908$, s. 242-243.

${ }^{45}$ A. Karanwanow, Srażenieto pri Sliwnica, [w:] Srbsko-błgarskata wojna 1885. Sbornik statii, red. J. Mitew, Sofija 1985, s. 74.

${ }^{46}$ Szerzej na ten temat: D. FAszcza, op. cit., s. 139-143.

47 D. ZAFIrow, Postiżenijata na błgarskoto woenno iskustwo w Srbsko-błgarskata wojna prez 1885 g., „Woennoistoriczeski sbornik” 1996, kn. 2, s. 174. 
zakończyło natomiast podpisanie traktatu pokojowego 3 marca 1886 r. w Bukareszcie $^{48}$. Długotrwałość wojny i intensywność walk spowodowały, że straty po obu stronach były niewielkie. W wyniku działań wojennych Bułgarzy stracili około 700 zabitych, a 4500 osób zostało rannych ${ }^{49}$. Po stronie serbskiej zginęło natomiast 746, żołnierzy, 4570 było rannych, a 1641 uważa się za zaginionych ${ }^{50}$.

\section{Czynniki geograficzne warunkujące przebieg wojen na ziemiach bułgarskich w drugiej połowie XIX w. (wybrane przykłady)}

Obie wojny przyniosły wiele ciekawych przykładów, jak czynniki geograficzne wpływały na przebieg walk. Kluczową kwestią, przed jaką stanęli rosyjscy i serbscy sztabowcy opracowujący plany wojenne był wybór kierunku głównego natarcia. Kierując się względami politycznymi i geograficznymi w obu przypadkach były to stolice wrogich państw: Konstantynopol i Sofia. Wśród czynników geograficznych, które przemawiały za takim rozwiązaniem była ich odległość od granicy. Wiązało się to jednak z pewnymi wyzwaniami, jakie towarzyszyły tej decyzji. Sztabowcy rosyjscy musieli uwzględnić potrzebę sforsowania dużej przeszkody wodnej, jaką był Dunaj, a następnie opanowania przełęczy bałkańskich, których posiadanie umożliwiało bezpośrednie skierowanie sił rosyjskich na stolicę Imperium Osmańskiego. Podobny problem stanął przed sztabowcami serbskimi. Co prawda, granica serbsko-bułgarska miała charakter otwarty i nie było tam istotnych przeszkód naturalnych, lecz na drodze do Sofii znajdował się Wąwóz Dragomański, którego uporczywa obrona mogła pokrzyżować plany szybkiego zajęcia stolicy Księstwa Bułgarskiego.

Pierwszą przeszkodą, z jaką musieli się zmierzyć żołnierze rosyjscy w $1877 \mathrm{r}$. był Dunaj, który należy do największych rzek Europy. Płynie z zachodu na wschód i wpada do Morza Czarnego. Jego szerokość w dolnym odcinku biegu wynosi od 750 do $1600 \mathrm{~m}$. Stan wody w rzece ulega okresowym wahaniom, przy czym najwyższy poziom wody utrzymuje się wiosną od drugiej połowy marca do początków czerwca (w 1877 r. okres ten wydłużył się do połowy czerwca). W końcu lipca i na początku sierpnia poziom wody w rzece ponownie się podnosi, a to za sprawą topniejących śniegów w Alpach. Wysokość i nachylenie brzegów rzeki są dogodne do prowadzenia obrony, a niekorzystny dla lądowania wojsk operujących z kierunku północnego. Lewy brzeg rzeki ma charakter niziny i jest silnie zabagniony, co utrudnia podejście. Brzeg prawy jest natomiast wysoki i urwisty.

48 Umowa o pokoju między Księstwem Bułgarii a Królestwem Serbii [podpisana w Bukareszcie 19 lutego/3 marca 1886 r.], dok. nr 5, [w:] J. Rubacha, A. Malinowski, A. Giza, Historia Bułgarii 1870-1915. Materiały źródłowe z komentarzami, t. I (polityka międzynarodowa), Warszawa 2006, s. 62.

${ }^{49}$ Istorija na Srbsko-błgaskata..., s. 793.

${ }^{50}$ Ibidem, s. 801. 
Wzdłuż bułgarskiego odcinka Dunaju jest 11 odcinków, gdzie prawy brzeg jest nieco obniżony, co ułatwia przeprawę wojsk. Część z nich była w 1877 r. strzeżona przez twierdze tureckie w: Widyniu, Nikopolu, Ruszczuku (ob. Ruse), Szumli (ob. Szumen) i Silistrze ${ }^{51}$. Dodatkowo rzeka patrolowana była przez tureckie okręty wojenne Flotylli Dunajskiej.

Uwzględniając te czynniki, dowództwo rosyjskie zdecydowało się przeprawić wojska na drugą stronę Dunaju realizując dwie operacje desantowe. Pierwszą, w rejonie delty rzeki pod Gałaczem i Braiłą, co miało jedynie odwrócić uwagę dowództwa osmańskiego ${ }^{52}$ i drugą, na wschód od Swisztowa, gdzie miały się przeprawić główne siły Armii Naddunajskiej ${ }^{53}$. O wyborze miejsca forsowania rzeki przez siły główne zdecydowały przede wszystkim czynniki wojskowe (możliwość szybkiego rozwinięcia działań ofensywnych), nie bez znaczenia pozostawały jednak także czynniki geograficzne. Teren po stronie rumuńskiej umożliwiał skryte przemieszczenie oddziałów rosyjskich i spławienie środków desantowych rzeką Aluta, a wyspy Ada i Bugirescu, dzielące Dunaj na dwie odnogi, ułatwiały budowę mostów pontonowych ${ }^{54}$. Rozpoczęta po północy 27 czerwca 1877 r. operacja desantowa pod Swisztowem potwierdziła słuszność decyzji co do wyboru miejsca przeprawy sił głównych armii naddunajskiej. Wykorzystując czynnik zaskoczenia, uchwycono przyczółek, a do wieczora pierwszego dnia operacji cały 8 Korpus znalazł się na drugim brzegu rzeki. Wkrótce potem, wykorzystując wybudowane dwa mosty pontonowe, na terenie Bułgarii znalazło się gros armii naddunajskiej ${ }^{55}$.

Siły rosyjskie operujące na terenie Półwyspu Bałkańskiego zostały podzielone na trzy zgrupowania: wschodnie, zachodnie i przednie. Oddział wschodni (ruszczycki) liczący początkowo około 45 tys. żołnierzy otrzymał zadanie neutralizacji sił tureckich znajdujących się w czworokącie: Ruszczuk-Silistra-Warna-Szumla i osłony lewego skrzydła wojsk nacierających na południe. Grupa zachodnia (35 tys. żołnierzy) miała za zadanie opanować Nikopol i Plewnę, a następnie zająć Starą Zagorę i osłaniać prawe skrzydło wojsk nacierających na południe. Liczący 10 tys. żołnierzy oddział przedni, dowodzony przez gen. lejtnanta Josifa Hurko, miał natomiast opanować przełęcze bałkańskie prowadzące na południe kraju ${ }^{56}$.

${ }^{51}$ Opisanie russko-tureckoj wojny 1877-78 g.g. na Bałkanskom połuostrow, t. I, Obstanowka pered wojnoj, S.-Peterburg 1901, s. 8-9.

${ }_{52}$ Opisanie russko-tureckoj wojny 1877-78 g.g. na Bałkanskom połuostrow, t. II, Woennyja dejstwija s 12 aprelia po 9 ijulia 1877 g., S.-Peterburg 1901, s. 110-111; M. Marinow, H. Uzunow, A. Karainanow, T. Dakow, op. cit., s. 54-55.

${ }^{53}$ Opisanie russko-tureckoj..., t. II, s. 135.

${ }^{54}$ Wojna rosyjsko-turecka..., s. 89.

${ }^{55}$ Szerzej na ten temat: Pereprawa czerez Dunaj u Zimnicy, dok. nr 10, [w:] L.G. Beskrowny,, op. cit., s. 473-482.

${ }^{56}$ Opisanie russko-tureckoj..., t. II, s. 186-187. 
Ofensywa oddziałów gen. J. Hurko przebiegała pomyślnie. Dnia 7 lipca 1877 r., po krótkiej walce, zdobyta została stara bułgarska stolica Tyrnowo, a wojska rosyjskie i bułgarscy ochotnicy zbliżyły się do pasma górskiego Starej Płaniny. Przekroczyć je można było przez cztery przełęcze: Szipkę, Triawneńską, Twyrdicką i Chankioj (ob. Republikańska). Najdogodniejszą do przejścia była położona na drodze Gabrowo-Kazanłyk przełęcz Szipka (1185 m n.p.m.). Była ona jednak ufortyfikowana i obsadzona przez wojska sułtana. Również pozostałe przejścia były kontrolowane przez Turków z wyjątkiem przełęczy Chankioj, która była uważana przez dowództwo tureckie za niedostępną dla wojska, o czym świadczy fakt, że szlak ten nie był nawet zaznaczony na mapach wojskowych ${ }^{57}$. Pomimo dużego ryzyka właśnie tędy Rosjanie postanowili przekroczyć pasmo górskie Bałkanów. Saperzy rosyjscy wspomagani przez ludność bułgarską poszerzyli na tyle szlak, że 14 lipca kosztem ogromnego wysiłku, oddział gen. J. Hurko przekroczył wąwóz i wyszedł na tyły wojsk broniących Szipkę. W tej sytuacji po krótkiej walce Turcy wycofali się ${ }^{58}$.

Przekroczenie Bałkanów przez wojska rosyjskie spowodowało reakcję dowództwa osmańskiego i przerzucenie z Albanii części wojsk pod dowództwem Sulejmana paszy z zadaniem powstrzymania dalszego marszu Rosjan na południe i przywrócenia kontroli nad przełęczami bałkańskimi. Pod koniec lipca i na początku sierpnia w wyniku ciężkich walk prowadzonych na linii Stara ZagoraNowa Zagora wojska rosyjskie zostały zmuszone do odwrotu i przejścia do obrony przełęczy prowadzących przez bałkański masyw górski ${ }^{59}$. Miejscem, gdzie Turcy zdecydowali się wykonać główne uderzenie była przełęcz Szipka.

Broniony przez niewielki (około 5,5 tys. żołnierzy) rosyjsko-bułgarski oddział pod dowództwem gen. lejtnanta Nikołaja Stoletowa wąwóz był otoczony wąskimi grzbietami górskimi zakończonymi urwistymi stokami. Broniąca do niego wejścia pozycja miał dwa kilometry długości i od 700 do 800 m szerokości. Składały się na nią okopy wykonane do pełnego profilu i stanowiska artylerii na czterech szczytach górskich, z których można było prowadzić ostrzał we wszystkich kierunkach. Dodatkowo na przedpolu wykopano wilcze doły, a na skrzydłach wykonano zawały leśne. Mimo podjętych starań umocnienia można było bez trudu obejść zarówno ze wschodu, jak i zachodu ${ }^{60}$. Tak przygotowana pozycja obronna wkrótce stała się miejscem zaciętych walk trwających od 21 do 23 sierpnia. Prowadzone one były w upale sięgającym $38^{\circ} \mathrm{C}$ i przy topniejących zapasach amunicji

${ }^{57}$ M. Marinow, H. Uzunow, A. Karainanow, T. Dakow, op. cit., s. 63.

${ }^{58}$ Szerzej na ten temat: Opisanie russko-tureckoj..., t. II, s. 188-239; M. Marinow, H. Uzunow, A. Karaiwanow, T. Dakow, op. cit., s. 64-65; M. Uyar, E.J. Erickson, op. cit., s. 187.

59 Wojna rosyjsko-turecka..., s. 108-110; P. PETRow, Rusko-turskata oswoboditelna wojna 18771878, [w:] Kratka woenna istorija na B'łgarija 681/1945, red. N.N. GACow, Sofija 1977, s. 166-169.

${ }^{60}$ M. Marinow, H. Uzunow, A. Karaiwanow, T. Dakow, op. cit., s. 86-88; K. Janczulew, Rusko-turskata wojna 1877-1878, wyd. 2, Sofija 1941, s. 63. 
oraz żywności, co szczególnie dawało się we znaki obrońcom. W efekcie stoczonej bitwy oddziałom rosyjsko-bułgarskim, które z czasem uzyskały wsparcie, udało się utrzymać zajmowane pozycje ${ }^{61}$.

Jeszcze raz czynniki geograficzne odcisnęły piętno na przebiegu walk o Szipkę za sprawą warunków klimatycznych w drugiej połowie listopada 1877 r. Wówczas to nadeszła surowa zima, która szczególnie dała się we znaki obrońcom przełęczy bałkańskich. Silne załamanie pogody spowodowało wstrzymanie aktywnych działań bojowych. Obrońcy pozostali jednak na pozycjach i rozpoczął się okres, który przeszedł do historii jako „siedzenie na Szipce”. Typowe dla tej pory roku burze śnieżne, które trwały nawet kilka tygodni i niska temperatura, która spadła do $-21^{\circ} \mathrm{C}$ spowodowały zakłócenia w dostarczaniu żywności i paszy. Trudności w dowozie materiałów budowlanych, mróz oraz kamienisty grunt uniemożliwił budowę wystarczającej liczby ukryć dla ludzi. Warunki służby były wyjątkowo trudne.

Odzież przemarzała, stawała się twarda i ograniczała ruchy, co zwiększało niebezpieczeństwo wychłodzenia - upadający nie byli wstanie się podnieść [...]. Żeby się ogrzać, ludzie biegają wokół transzei ${ }^{62}$.

Efektem tego był wzrost zachorowalności wśród żołnierzy, a przypadki zamarznięcia żołnierzy nie były odosobnione. 8 grudnia 1877 r. wśród obrońców Szipki chorych było 90 oficerów oraz 6034 podoficerów i szeregowych ${ }^{63}$. Mimo tych skrajnych warunków obrońcy utrzymali zajmowane pozycje.

Pogoda także miała wpływ na przebieg walk na innych odcinkach frontu. Znamiennym przykładem może być trzeci szturm Plewny przeprowadzony 11 września 1877 r. w dniu imienin cara Aleksandra II. Starając się przypodobać władcy, rosyjskie dowództwo zlekceważyło czynniki pogodowe i nakazało szturm umocnień tureckich. W noc poprzedzającą atak i całe przedpołudnie padał deszcz, który później zamienił się w mżawkę ${ }^{64}$. Spowodowało to, że grunt rozmiękł, zmniejszając skuteczność ostrzału artyleryjskiego i utrudniając przemieszczanie się nacierających kolumn rosyjskich. Błoto wytłumiło falę uderzeniową eksplozji oraz rozpraszanie się odłamków pocisków artyleryjskich i w dużym stopniu wyhamowało impet uderzenia rosyjskiej piechoty. Dodatkowym czynnikiem pogodowym, który miał wpływ na przebieg szturmu, była utrzymująca się do godz. 11.00 gęsta mgła. Fakt ten spowodował, że artyleryjskie przygotowanie ataku

\footnotetext{
${ }^{61}$ Szerzej na ten temat: M. Marinow, H. Uzunow, A. Karaiwanow, T. Dakow, op. cit., s. 89-98.

${ }^{62}$ Iz dnewnika 55-go pehotnogo podol'skogo połka za wremja oborny Szipki, dok. nr 16, [w:] L.G. BESKROWNYJ, op. cit., s. 496.

${ }^{63}$ Ibidem.

${ }^{64}$ K. JancZulew, op. cit., s. 85.
} 
zostało skrócone, a artyleria nie wykonała pierwotnie zaplanowanego ostrzału ${ }^{65}$. Miało to niewątpliwie wpływ na przebieg walki i było jednym z powodów załamania się szturmu.

Czynniki geograficzne odegrały ważną rolę także podczas wojny serbsko-bułgarskiej 1885 r. Podobnie jak podczas omawianego powyżej rosyjsko-tureckiego konfliktu zbrojnego, na czoło wysunęły się kwestie związane z ukształtowaniem terenu i warunki atmosferyczne. Brak dużych przeszkód wodnych na obszarze objętym zmaganiami militarnymi spowodował, że nie odegrały one istotnej roli $\mathrm{w}$ tej wojnie. Problematyka ukształtowania terenu miała znaczenie podczas określania kierunku głównego uderzenia wojsk serbskich. Tu również o jego wyborze zdecydowała niewielka odległość od granicy do Sofii oraz relatywnie dogodne warunki terenowe sprzyjające prowadzeniu natarcia ${ }^{66}$. Prowadzone one były w dużym stopniu w Kotlinie Sofijskiej, która głęboko się wcina w głąb terytorium bułgarskiego. Kotlina Sofijska ma długość $75 \mathrm{~km}$, a jej szerokość waha się od 5 do $20 \mathrm{~km}$. Średnia wysokość wynosi $550 \mathrm{~m}^{67}$. Dolina jest częściowo pagórkowata i pokrywa ją roślinność typu śródziemnomorskiego (dęby krzewiaste z domieszką roślin laurolistych, cyprysowatych i mirtowatych ${ }^{68}$. Po serbskiej stronie granicy teren Kotliny Sofijskiej jest bardziej zalesiony niż w bułgarskiej części i charakteryzuje się większą liczbą dolin ${ }^{69}$. Wzdłuż niej przebiega fragment międzynarodowego szlaku prowadzącego z Wiednia przez Belgrad, Nisz, Sofię, Płowdiw do Konstantynopola. Liczący 57 km odcinek trasy łączący Sofię z położonym po serbskiej stronie granicy Pirotem stanowił główną oś natarcia wojsk serbskich w 1885 r. Na jego szlaku znajdowały się miejscowości: Caribrod (ob. Dimitrowgrad), Dragoman i Sliwnica. Na północ od niego znajdowały się dwie lokalne drogi umożliwiające dotarcie z Pirotu (przez Godecz) do stolicy Bułgarii ${ }^{70}$. Znaczenie tego kierunku operacyjnego podkreślał również fakt dobrego skomunikowania leżących na tyłach wojsk serbskich Pirotu i Niszu z Belgradem.

W marszu na stolicę Bułgarii wojska serbskie, oprócz rozbicia słabych sił osłonowych, musiały przekroczyć Wąwóz Dragomański. Broniony on był przez nieliczne siły bułgarskie (batalion piechoty, cztery kompanie (czety) ochotników i pół baterii artylerii), które po krótkotrwałej walce zostały częściowo rozproszone, a częściowo wycofały się na główną pozycję obronną w Sliwnicy ${ }^{71}$.

\footnotetext{
65 Ibidem.

66 Decyzję o jego wyborze podjął osobiście serbski władca król Milan. Szerzej na temat towarzyszących temu rozbieżności i dyskusji: D. FAszczA, op. cit., s. 107-109.

${ }^{67}$ H. Maruszczak, Bułgaria..., s. 125.

68 IDEM, Bułgaria, [w:] Geografia powszechna..., s. 109.

69 S. PAPRIKOW, Srbsko-błgarskata wojna 1885, Sofija 2011, s. 210.

70 Istorija na Srbsko-błgarskata..., s. 167.

71 S. PAPRIKOW, op. cit., s. 295.
} 
Co ciekawe, walory obronne, jakie posiadał Wąwóz Dragomański nie zostały także wykorzystane przez wojska serbskie podczas odwrotu po przegranej bitwie pod Sliwnicą. Broniące wschodniego wejścia do wąwozu oddziały Dywizji „Drina” po jednodniowych walkach (22 listopada) opuściły na rozkaz stanowiska obronne i wycofały się na terytorium serbskie ${ }^{72}$.

Duży wpływ na przebieg walk i funkcjonowania systemu zaopatrzenia wojujących stron w 1885 r. miały warunki klimatyczne. Charakterystyczne dla późnej jesieni (listopad) opady deszczu spowodowały, że nieutwardzone drogi za sprawą błota stały się trudno przejezdne. Spowodowało to, że w czasie odwrotu żołnierze oddziału kpt. Nikoli Genewa zmuszeni byli porzucić armaty ${ }^{73}$. Umięszona maź utrudniła także działania bułgarskiej kawalerii np. podczas walk 27 listopada 1885 r. w pobliżu wsi Gnjilan, niwelując jej atuty w postaci szybkości i manewrowości ${ }^{74}$. $Z$ problemem opadów deszczu, a później deszczu ze śniegiem musiały się zmierzyć także oddziały bułgarskie przerzucone znad granicy turecko-bułgarskiej w rejon walk. Przemoczeni, przemarznięci (część oddziałów miała letnie mundury) żołnierze, brnąc po kostki w błocie, pokonali średnio około $250 \mathrm{~km}, \mathrm{z}$ czego $95-135 \mathrm{~km}$ marszem pieszym, co zajmowało im dwa-trzy dni ${ }^{75}$. Utrudnione zadanie miały także bułgarskie kolumny transportowe przewożące amunicję i zaopatrzenie $\mathrm{z}$ głębi kraju w rejon walk na zachodzie kraju. Sytuację komplikował fakt ograniczonej liczby dróg, którymi mogły przemieszczać się kolumny transportowe. Konie i pojazdy szybko zatem rozmiesiły rozmokłe drogi na błoto.

Znaczną przeszkodę stanowiły również mgły, utrudniające obserwację, a nawet wręcz uniemożliwiające prowadzenie walki. Utrzymująca się przez kilka godzin mgła wyraźnie skracała czas prowadzenia efektywnej walki - i tak krótki, biorąc pod uwagę porę roku. To właśnie gęsto zalegająca mgła spowodowała opóźnienie rozpoczęcia natarcia Dywizji „Morawa” na Tryn 15 listopada 1885 r. $^{76}$ Podobnie rzecz się miała w godzinach wieczornych za sprawą opadającej mgły. To zjawisko atmosferyczne umożliwiło pułkom Dywizji „Drina” sprawne wycofanie się po nieudanym ataku w pierwszym dniu bitwy pod Sliwnicą ${ }^{77}$.

${ }^{72}$ Kratka istorija na Srbsko-błgarskata wojna prez 1885 g., Sofija 1943, „Woennoistoriczeski sbornik" 2006, kn. 1-2, s. 114.

${ }^{73}$ E. Bugarczewa, Spomienite na generał Nikoła Ganew za Srbsko-błgarskata wojna i dejstwijata na Trynskija otrjad, „Izwestija na drżawnite arhiwi” 2005, br. 89, s. 278-279.

${ }^{74}$ Kratka istorija..., s. 124.

75 D. Zafirow, op. cit., s. 174-175.

${ }^{76}$ Colonel Regenspursky, The Serbo-Bulgarian War of 1885. Combat at Slivnitsa, trans. G.F. NAFZiger, West Chester 2007, s. 104.

77 A. Karanwanow, op. cit., s. 86. 


\section{Podsumowanie}

Czynniki geograficzne odgrywały ważną rolę podczas wojen prowadzonych na terenie Bułgarii w drugiej połowie XIX w. Wojujące strony w pierwszym rzędzie musiały uwzględniać specyficzne warunki terenowe. Zmuszone były także sprostać wyzwaniom stawianym przez klimat, budowę geologiczną, glebę oraz sieć hydrograficzną. Wszystkie one były, szczególnie w przypadku strony rosyjskiej, przedmiotem zainteresowania sztabowców już na etapie planowania działań militarnych.

W tym miejscu należy jednak zauważyć, że ówczesny stan wiedzy na temat właściwości geograficznych Półwyspu Bałkańskiego był niewielki, a jego obszar był najmniej poznanym rejonem Europy ${ }^{78}$. Najlepiej o tym świadczy fakt, że w 1877 r. Rosjanie dysponowali jedynie 17-arkuszową mapą tego obszaru sporządzoną przez płk. Nikołaja Artamonowa oraz specjalnie na ich potrzeby wykonaną mapą autorstwa znanego austriackiego podróżnika i grafika Feliksa Philipa Kanitzy $^{79}$. Oprócz tego komitet wojskowo-naukowy wydał w nakładzie 750 egz. dwie broszury będące zbiorem podstawowych wiadomości na temat przyszłego obszaru walk zatytułowane: Bałkany i Trasy przemarszu przez Półwysep Bałkański ${ }^{80}$.

Jeszcze gorzej sytuacja wyglądała w 1885 r. Dowódcy serbscy nie przykładali należytej wagi do czynników geograficznych, co wynikało przede wszystkim z faktu lekceważenia możliwości stawienia oporu przez przeciwnika i głębokiego przeświadczenia o szybkim zakończeniu wojny. Wojska serbskie posługiwały się w tym czasie austriackimi mapami topograficznymi. W dostępnej literaturze przedmiotu nie natrafiono natomiast na informacje o istnieniu jakichkolwiek studiów terenu wykonanych na potrzeby prowadzonej wojny. W związku z niedostatkiem wiedzy na temat czynników geograficznych przyszłego obszaru walk dowódcy walczących stron zostali wielokrotnie zaskoczeni przez siły natury i musieli na bieżąco reagować na występujące utrudnienia. Miały one szczególnie ważny wpływ na kwestie związane z zabezpieczeniem logistycznym wojujących armii, ale także odcisnęły się na przebiegu walk np. w czasie trzeciego szturmu Plewny. Podejmując się trudu opisania tych czy też innych wojen, kampanii czy bitew, nie można o tym zapominać.

${ }^{78}$ Szerzej na ten temat: B. Jezernik, Dzika Europa. Bałkany w oczach zachodnich podróżników, tłum. P. OczKo, Kraków 2007, passim.

${ }^{79}$ F. Kanitz był także autorem pracy Donau-Bulgarien und der Balkan. Historisch-geographisch -etnographische Reisesstudien aus den Jahren, 1860-1878, Leipzig 1875-1879, stanowiącej plon jego wieloletnich podróży po Bałkanach, M. Todorova, Bałkany wyobrażone, tłum. P. SzYMOR, M. BUDZIŃsKa, Wołowiec 2008, s. 159, 426.

${ }^{80}$ Opisanie russko-tureckoj..., t. I, s. 26-27. 
Czynniki geograficzne w znaczeniu tego słowa zaproponowanym przez Zygmunta Paruckiego odgrywały i nadal odgrywają ważną rolę w procesie planowania i prowadzenia działań wojennych. Świadomość taką mają wojskowi i powinni ją mieć także historycy zajmujący się odtwarzaniem zmagań militarnych. Ich poznanie stanowi pewną wyodrębnioną sferę badawczą określoną przez prof. Jana Tyszkiewicza jako „krajobraz wojenny” ${ }^{81}$. Niestety praktyka wskazuje, że czynniki geograficzne są często pomijane lub sprowadzane do kilku zdawkowych stwierdzeń. Rzadko stanowią one przedmiot analiz i studiów, w tym studiów terenowych, które pozwalają na bezpośrednie poznanie terenu, gdzie toczył się bój. Brak tej wiedzy powoduje tym samym, że przekaz jest niepełny, co szkodzi procesowi uchwycenia i ocenienia przebiegu opisywanych wydarzeń. O potrzebie uwzględniania czynników geograficznych i studiowania ich podczas odtwarzania kampanii wojennych i bitew pisał już dawno temu wybitny polski historyk Benon Miśkiewicz, nadając im dużą rolę „,w postępowaniu badawczym historyka wojskowego"82.

\section{Dariusz Faszcza}

\section{THE ROLE OF GEOGRAPHICAL ENVIRONMENT DURING THE WARS IN BULGARIA IN THE SECOND HALF OF THE $19^{\mathrm{TH}}$ CENTURY}

Summary: The knowledge of geographical conditions is one of the main requirements for planning military operations at each command level. The natural environment enforces the variety of combat techniques. It is a truism, therefore, to say that every military historian reconstructing the course of wars or war campaigns should analyze the impact of natural conditions on the battle planning process and its course.

The article presents the characteristics of Bulgarian area and the impact of geographical conditions on the course of military operations during the Russian-Turkish war of 1877-1878 and the Serbian-Bulgarian war of 1885. Although they were two different conflicts in terms of duration, number of forces and direction of conduct, their example shows the problems faced by fighting armies at the time. We are dealing with issues related to overcoming the swollen waters of Danube and battlefields abounding in hills and mountain passages difficult to access. Not without significance were weather issues, which influenced the course of the fight and the possibilities of supplying troops.

Keywords: Bulgaria, military geography, geographical factors, Russian-Turkish war 1877-1878, Serbian-Bulgarian war 1885.

\footnotetext{
81 J. TyszkiewiCz, op. cit., s. 142, 147.

82 B. MiśKiewiCZ, op. cit., s. 137.
} 